\title{
Social Democracy in a Global Era
}

\author{
Luke Martell
}

A version of this will be in Olaf Cramme and Patrick Diamond eds, After the Third Way: the future of social democracy in Europe, IB Taurus, forthcoming 2012

In the triumvirate of capital, labour and state, capital has long been a problem for the other two. Social Democracy has historically represented labour, especially in the UK where the Labour Party was born out of the trade union movement, and used the state as an agency to achieve its aims. But social democratic goals of redistribution and regulation are often not in the interests of capital, or not seen to be. And capital has pressured social democratic governments to restrain policies that involve such ends.

\section{Global Capital and National Social Democracy}

From the 1970s onwards capital's power has grown. It has increased power of exit as well as voice. It can threaten social democrats that it will leave the country if governments pursue policies too much against its interests. This has been facilitated by political and technological changes that have expanded the possibility of capital flight. Relaxed regulations on the movement of capital and developments in information technology make it easier to move huge amounts of money in and out of countries very quickly. Governments that want to ensure a buoyant economy with investment, jobs, and revenue they can tax to support welfare and public services are under pressure to moderate egalitarian and welfarist policies and acquiesce to capital to make sure it stays in the country.

States compete with one another to offer the policies most amenable to capital to tempt it to come to them. Such policies tend to be neoliberal. So a number of consequences follow: competition amongst states; preferences for neoliberal over social democratic policies; convergence as states orient around the same sort of neoliberal policies to attract capital; and an erosion of democracy as governments make policy choices in response to the wants of unaccountable capital rather than the voters who elect them. For some this involves a 'race to the bottom' - low taxes, weak regulations to protect labour and wages, a reduction in welfare and public services funded by tax, a rolling back of redistributional policies, and restrictions on reflationary economics which are seen to damage financial confidence and deter investors. In short, a reduction to a lot of what defines social democracy, and the least social provision possible to persuade businesses you provide a low cost location for them.

There is no doubt that capital, and increases in the possibility of capital mobility, put strong pressures on governments who want to pursue social democratic policies. This pressure should not be underestimated, but it can be exaggerated and there are reasons to believe there is space for national social democracy. For some on the right and centre-left it has become common sense that social democracy has to adapt to a politics of low taxes, limited redistribution, prudent public spending, a more marketised public sector, and deregulation. But the argument does not stand up as well as at first it seems (see, for instance, Mosley 2005). 
It's important to test theories against empirical evidence and the argument that social democracy needs to be modernized in the face of globalisation, which means move away from historical forms of social democracy, is less powerful when you look at what actually happens. There are some very globalised countries in the world where some old tenets of social democracy keep going along quite well. Countries like Sweden, Germany and France, are vulnerable to the movement of capital abroad yet maintain bigger welfare states, higher rates of tax and social spending, less inequality, stronger trade unions, and stronger cultures of respect for the state and public sector than in other European countries and places like the USA. Yet they do not suffer major losses of capital overseas and their economic performance is comparable to and, in some respects, better than that of countries with more neoliberal policies like the US and UK. Not only do they maintain social democratic institutions and retain capital, they have some of the best standards of living in the world. Such countries also run up deficits without damaging financial confidence. Where governments are cautious about inflation and deficits there is often less reluctance about increasing social spending and the taxation needed to support it.

Beyond Europe, countries like Argentina and Venezuela have defaulted on loans, nationalized major companies, or had substantial programmes of social spending, often talked up with leftwing anti-globalist rhetoric, yet attracted large amounts of foreign investment from countries like the US. Globalization in such places in Europe and Latin America is overridden by domestic cultures and politics that support more social democratic policies. Furthermore states in these regions have things that are attractive to mobile capital - education and infrastructures of health and social support which reduce costs for business, advanced technology, skilled workers, consumer markets, networks of suppliers and so on.

Exposure to the global economy, whether through reliance on external investment and finance, or integration into networks of imports and exports, or the involvement of multinational corporations, may lead electorates to call for more social democracy not less, to provide compensation for the social effects of globalization. Such effects include instability, insecurity, and the possibility of heavy shocks like the global financial crisis. Here state intervention is needed economically to bail out capitalism, regulation to guard against phenomena like undue risk-taking, and support for people who suffer the social effects, such as unemployment.

Having a healthy social infrastructure is not just good for people feeling the effects of globalization. It is good for businesses looking to exploit its advantages for their own gain. Investment in education and training, in health, social support for those unskilled, excluded or unemployed are all good for companies. They ensure a skilled, healthy workforce, provided by the state, and take away the need for direct provision of such infrastructure by businesses themselves. In addition, such policies boost employment, and so also tax revenues, which is good for social democracy that relies on tax for public spending.

Amongst rich country lefts there is much that is social democratic that can be done in a context of mobile capital. But many of the attractions mentioned are less possible in developing countries, especially those in the lowest tiers. There is less to offer and so the pressure to pursue neoliberal policies to attract investment is much stronger there. For social democracy, this means there is a need for international solidarity across the global left. Social democrats in richer countries should build links with the left globally to support social democracy in poorer places. 
Internationalism, which used to be central to left thinking, is now more out of the picture, and behind the globalism of capital. Social democracy needs to be more international. But, as we shall see, this does not necessarily mean global politics at central institutional levels.

So the theory of mobile capital ruling out social democracy sounds plausible but, in better off countries, fails empirical tests. Yet, as Bourdieu (1998) has argued, it has become common sense, not just for the right but also the centre-left, such that anyone who argues against this perspective is seen as out of touch, and unable to get real and be forward looking. There has been a shift from a belief in a mixed economy, markets alongside welfare, redistribution and Keynesian economics to a view which sees these as no longer feasible under conditions of globalization, or even that desirable. A model of modernized new social democracy is of more markets and private provision in the public sector, deregulation, and inclusion of the worst off in society replacing egalitarianism as a goal. The difference between new social democracy and the new right becomes less a qualitative one and more an issue of the degree and extent of neoliberalism rather than the questioning of it. What marks social democracy off as distinctive equality, regulation, public welfare, and reflationary economics - is eroded and space for a mainstream alternative to neoliberalism begins to look empty of occupants. Globalization is an external justification for this.

\section{Global Social Democracy}

But even if there is scope for social democracy nationally, there are still reasons why it should be pursued internationally. The question is, how? Is there space for social democracy globally, to unite with the left in other parts of the world beyond the UK and Europe, and in global political institutions where global problems such as economic regulation and climate change can be tackled?

Global problems like international economic instability, inequality between the rich North and the poor South, and climate change require global politics to solve them. Citizenship, constitutional power and democracy are based at national levels yet national governments are decreasingly up to the job of tackling such problems alone. It is argued that global levels are where governance needs to be done. Consequently such features of democracy need to be moved from national to global institutions. From this point of view, we need inclusive global governance organisations, like the UN, perhaps combining many that exist at the moment in fragmented form, from the United Nations to the World Bank and International Monetary Fund and others. Global fora could be composed of all national actors, given formal global constitutional status, and with lines of democracy or even citizenship. It is at this level that effective decisions on global problems of insecurity, inequality and environment can be made (see, for example, Held 2004).

Social democracy should play no small part in this, given its historical role as an egalitarian and regulatory politics, and social democrats need to make sure their beliefs get majority or hegemonic status in such institutions. To do this, it is argued, social democrats have to shed their attachment to change purely at and through the national level. Regulation for social ends, greater equality, social welfare, and stimulus economics are good nationally so should also be globally. Responsibility to others should not extend just to our nearest and dearest but to humans across the world. There is nothing in social democracy that says that charity should be 
confined to home. However, we should ask whether having social democratic values at a global level means that social democratic politics at a global level is the right way to achieve these.

Are there social and cultural bases for global social democracy? Social democratic values are longstanding and have become mainstream in many places, beyond social democratic parties the importance of state welfare, health and education, a belief in greater equality, and the need to regulate, for instance, unaccountable finance. British Social Attitudes surveys show that such values survived intact in Britain through the neoliberal Thatcher years. Furthermore, for the elected left to maintain power and enact policies a major shift to left values across the public does not seem essential. An image of Latin America in recent years is of region through which a wave of leftism has spread. But left parties there have pulled on non-left as much as left values amongst the public (Morales 2008). Many people who support the left are not of the left, but vote for it because it seems competent and effective and delivers policies that tackle problems like poverty. So there is a social basis for social democracy, consisting of values of traditional social democracy, and support that can be won across the board by simple political effectiveness.

But is there a social or cultural basis for a global social democracy? World values surveys show that not that many people hold global cosmopolitan values. They identify with local or national identities many times more frequently than with global identities or with those at great distance from themselves (Norris 2000). Attitudes to immigration in rich countries are frequently hostile to outsiders, in a way that is out of touch with evidence on the positive benefits of immigration (Martell 2010: chapter 6). Social democratic politicians foster this prejudice when they attribute problems like housing shortages or low wages to immigration rather than to social democratic issues like the rundown of state housing or weak labour protection. The cultural basis for social democracy may be holding up but it is less clear what cultural basis there is for a more globalist and cosmopolitan form of this.

Even if there were a cultural basis worldwide for more global and cosmopolitan governance this may well not be replicated in politicians' behaviour. Where there are attempts at inclusive, formal, institutionalised global politics it often breaks down over the competing material interests of different states, or results in agreements which are effectively unbinding and not honoured. This happens in talks on world trade, climate change, debt relief, and nuclear proliferation in fora such as WTO talks, COP15, the G8 and the Nuclear Non-proliferation Treaty. Furthermore, some states in such fora have far more influence, even if formally all are equal, and can counter globally or social democratically minded policies. The US and China, for instance, wield much greater power in world trade and climate change talks than most other nations.

For global politics to take a social democratic direction there would have to be a coinciding of social democrats in a majority of states across the world, or of agencies willing to put forward social democratic norms in global institutions. For Gamble social democrats have to ensure 'that the global polity, and not just the national polity, is governed by social democratic values and norms' (2009: 125-6). But this prescription is made in a context in which social democrats find it hard to get into national governments, let alone many at once in global governance, and then find it difficult to carry out social democratic programmes when they do because of internal battles, revisionism away from social democratic values, electoral pressures and perceived external constraints. 
Even in a restricted transnational forum like the regional EU, the dream of a plethora of social democratic parties in power at once in its different countries has rarely occurred and when it did in the late 1990s they spent a good part of their energy introducing a more economically liberal union rather than a social democratic 'social Europe'. A more realistic and, therefore, more productive international social democracy would be one where international social democrats form alliances with other social democrats and left parties and movements where they are across the world, and have things in common, away from all-inclusive institutionalised global fora where it would be hard to build a majority with a social democratic ideology which could be sustained against powerful opposition from other actors and from within.

\section{Social Democracy in International Politics}

Formal global governance, inclusive and top-down, involves multiple possibilities for clashes of interest. Consequently, a conflict understanding of politics is as good a route for social democracy as a dialogical approach that aims for agreement at central global level. Conflict approaches recognise clashing material interests, inequality and power. They are compatible with participation in central global institutions, but on the basis that social democratic ends will have to be pursued against opposed forces that have anti-social democratic objectives and power, as much as through agreement between actors with contradictory interests.

There often are not effective means for enforcement of policies above national levels. An equally good approach for pursuing social democratic goals is building up from existing initiatives, from national laws that can be made and enforced more easily, and bilateral agreements on social democratic policies where there are fewer parties involved, so more chance of things being achieved. In addition, the other side of competition with those who have conflicting interests is collaboration with actors who are like-minded and have similar interests, in selected alliances. This is below-global but still international, because it involves reaching out beyond nations to wider links, if not inclusion of all. It is bottom up - alliances with the likeminded lower down rather than everyone at a global level. It is not inclusive. You ally just with those you can get agreements with. Leaders of the Latin American left have tried such an approach. International social democracy requires finding lefts where they are and building links between them, a global left rather than global government.

Bottom-up internationalism starts with activities locally and nationally and generalizes up to the global level, rather than creating global deals in an impossible situation of inclusive conflicting interests and going down from there. This includes civil society. Global justice movements have been important in pushing social issues on to the political agenda - for example, the exploitative practices of multinational corporations, third world debt, and proposals for taxes on financial transactions. Greater engagement with social movements in civil society will require reaching back by social democrats to roots in the workers' movement and trade unions and crossways to places like Latin America where the left has social movement bases such as trade unions and movements around indigenous people's rights.

At the same time, the state is part of the traditions of social democracy and is important. Antistatism and leaving everything to civil society will endanger social democratic concerns such as equality and wider collectivism. The state can be overarching and for the collective good of the people, taking into account collective needs not met by the market, and redistributional 
questions. Handing state activities to civil society means people have to look after themselves when sometimes it is good for the government, democratically accountable with collective goals, to help rather than leave people to it alone, individually or solely through voluntary associations. Some people want a democratic government to provide equality and security. An associational society needs mechanisms to maintain equality and collective provision across it, and this involves central state government.

International social democracy needs to be multi-dimensional, operating at a number of levels below formal global institutions. It can also be experimental - building from initiatives already in play bottom-up, including from civil society, rather than from abstract agreements top-down which may not be tried or tested, and are often effectively unbinding. Examples of ideas or practices from below which are in tune with social democracy and have or can be acted on include: 1) forms of taxation to fund development, environment or the public sector, such as the Tobin or Robin Hood tax; 2) debt cancellation; 3) co-operative types of ownership; 4) examples of the regulation of markets in different states; 5 ) environmental and climate change initiatives which go beyond targets and involve actual practices like electrical vehicle and turbine innovations, deforestation, and solar power developments; 6) social programmes like Lula's Bolsa familia in Brazil and Chavez's missions in Venezuela; and 7) minimum, social or living wage ideas. These have emerged from civil society, the private sector, social movements and states, not global governance.

So global institutions may not always be the best means for globally minded social democracy. But being skeptical about global institutions for social democracy does not mean skepticism about globalist social democratic ends, such as international equality and responsibility and global issues to do with the economy and environment. The development of world capitalism calls out for a global social democracy in ends, but pursued through below-global means.

\section{The Content of New Social Democracy}

If social democracy is possible, nationally and internationally, in a globalised era, what should it be about? New social democrats argue that social democracy has lost its ideological direction. It is hooked on out-dated ways of thinking and needs to renew its ideas to be applicable to the important issues of the day. Central to this is open-mindedness about the interpenetration of market and state, including the role of the market in rejuvenating the state and public sector. This follows the third way's emphasis on balancing economic efficiency with social justice, rather than preferring the latter over the former, and seeing the market and state as not opposed but increasingly difficult to differentiate, the market being needed to shake up and revive the public sector, the traditional sphere of concern for social democracy.

But social democracy's emphasis should not be on allowing the market into the state. It should be on regulating markets. Revisionist centre-left arguments about the role of the market are for a time when it was perceived that social democrats were too fixated on the state and dogmatically against the market. In fact social democrats have always been more anti-market in rhetoric than in practice. Furthermore the time of anti-market dogmatism has passed and neoliberalism has become the hegemony or common sense. In this context talk should not be of balancing economic efficiency and social justice. This has become a given and the driving force is economic efficiency over social justice. What makes social democracy distinctive from liberalism 
and conservatism has been its emphasis on regulating the market. Now the market has centre stage and is widely celebrated, the thrust of social democracy should be on regulation of markets by the state in pursuit of the public good, rather than balancing of state with market or allowing the market into the state.

Instead of mixing up state and market, social democracy needs to keep them separate. It should be emphasising their distinct logics, and keeping under control and constraining market logic, which is individualistic, inegalitarian and about profit, in favour of state logic, which, in social democratic hands, is about equality, social justice and human goals over commercial ones. It is sensible to see that the state is not always the best type of organization, and the market often best for many areas of production and distribution. But it is also important ideologically to maintain boundaries between state and market so that the former can be seen as something that regulates and constrains the latter, and steps in where it is not the best form of organization. Where boundaries between state and market are seen as very permeable, and breaking them down a virtue, the danger is that the market intrudes into areas of state activity, introducing inegalitarian dynamics and commercial criteria where the state became involved to promote equality and the collective good.

Take the case of UK higher education. Public funding from taxation is declining and private finance from students is increasing. New Labour's introduction of student paid fees started this process. A new breed of manager is being introduced to advance it, whose approach is authoritarian rather than consensual, and with a business rather than a public good perspective. Means and ends are being reversed: universities are changing from institutions that raise money to provide quality education for the collective good, to business machines where education is a commodity used to produce profit. Areas of higher education are cut or expanded on economic rather than educational grounds, promoting inequality - between universities, students, social classes, and management and employees. There is restructuring within universities, with directly commercial areas expanding and critical and humanistic areas under threat. The progressive incursion of the market and private consumer into UK higher education, rather than providing resources to enhance the public sector is changing the meaning of education, from the aim of the public good to private profit with consequences for its structure and content.

Whilst it is important not to be dogmatic, there are dangers with making the boundaries between state and market too porous, so that the intrusion of the market into the public sphere dilutes objectives of equality, regulation and community. New social democracy argues for more interpenetration of state and market and less distinct boundaries between them in the name of open thinking. But this runs the risk of eroding the distinctiveness of what social democracy is. The consequence is that the historical actor that has occupied the space in mainstream politics where equality and collective public institutions are advanced, and the market is regulated and restrained, leaves this space empty. It does so in a context where the market and private sector are the norm, on the up and eroding collective and public values, exactly where social democracy is needed as an antidote. This is not an argument against open-minded thinking about the role of the market. But in the context of deregulation and the rise of neoliberalism it is important to have a perspective that stresses where the market is limited and needs to be constrained and regulated. If social democracy does not take on such a role in a post-Thatcherite neoliberal era no one else in the political sphere will. Those who want to defend the public good will have to 
take to the streets, which is what has happened in relation to the marketization of UK further and higher education.

\section{Social Democracy's Global Political Rudder}

Social democracy has not so much lost its ideological rudder. It has a long history as an ideology that has been successful in practice improving the conditions of working class people. It has had a credible approach to government, part of building welfare capitalism. It is more relevant than ever when rising inequality and lack of regulation of the economy are contemporary problems. The question is what are the political bases and spaces for pursuing a regulatory and egalitarian social democracy, which must be more about the state and public good than about the market, or it loses what is distinctive about it and the values it aims to pursue, equality and the collective good over individualism. If social democracy has gone astray somewhere, it is more that it needs to find the right political rudder.

The problem is a politics of support and government, as much as a new ideology for these. The question is not revising what ideologically demarcates social democracy from others in the name of modernisation; it is about finding the right places and alliances it can build social democracy from. Global levels offer some chances for this, but only some, heavily contested by more powerful forces. Global left alliances offer chances that global government does not. National levels have not been swept away. And local initiatives on the ground offer existing initiatives that can be built from.

One example where there is ideological insight but has been less political traction is the financial crisis. Lack of regulation of finance was part of the problem. As an historically regulatory politics, social democracy is well placed to bring in such an approach where it is needed and there has been a process, the financial crisis, that provides a basis for regulatory arguments. An ideological identity for social democracy is not lacking here, and it is not, in such circumstances, out of date. What have been missing are the political will, leverage and cross-national co-ordination to implement this.

Another classic social democratic approach is reflation. Reflation worked towards saving capitalism during the financial crisis. Governments poured money into national economies to keep them afloat, while global regulation was bypassed. Ideological principles - reflation and regulation - are present and relevant but the issue is the political will and spaces to carry them out. After neoliberalism and the financial crisis how is the ideology of equality and regulation out of touch and social democracy losing its way ideologically? The problem is not ideology but political leverage. Making the problem ideology takes us down a path that takes away from social democracy, what makes it distinctive and counters the right.

Governing strategy is in part about starting where social democracy is possible or working, which may sometimes be in civil society, sometimes with the state doing things for the people, sometimes with the market and exploiting or regulating it, or sometimes with state provision and democratising it. Social democracy can seek initiatives which are being developed or work, which have a regulative or redistributional element to them, and work with them, maybe local initiatives being generalised or developed nationally or internationally, where governance occurs. Going downwards this involves looking for these in civil society, in associations and social 
movements (eg the Robin Hood tax which started with ideas in the ATTAC movement). Going sideways it involves looking at other states and developing their ideas (eg from the Latin American left), or building links with them so policies can be carried out cross-nationally lessening the possibilities for capital flight. Looking upwards it involves fora at a global level where such initiatives can be slotted in although, while such spaces should be used where possible, contending and conflicting forces there make this a less propitious area to develop policy. Internationally policy is best pursued with those most likeminded and co-operative where you can find them, rather than across a table with the more powerful who have diametrically opposed ideologies and interests.

\section{Conclusion}

Does globalization mean that we need to construct a new and global social democracy? Globalization, neoliberalism and markets expanding into the state have not shown the need for reconstruction towards a new social democracy. They have shown the effectiveness of a reflationary approach, and the necessity of a regulatory, egalitarian social democracy oriented to the public good. We need to go back to go to the future. If we do not then important goals of equality and collectivism are lost, social democracy loses what makes it distinctive, and the political space which protects such values is left empty and without a political actor. Agents in civil society will have to take matters into their own hands.

And while globalization has shown the importance of social democracy as an ideology, it has not shown social democracy in global governance to be the level where it should operate. Here the prospects for left success are dim, consisting of powers opposed to it, and unlikely prospects for social democratic power coinciding across the world to make a majority. Under globalization the best prospects for social democracy are with building from experiments shown to work on the ground, at the national level where considerable leverage is still available and in the international collaboration of a global left between social democrats and other likeminded forces amongst governments, parties and social movements. Social democracy needs to seek out a global left more than global government.

\section{References}

Bourdieu, Pierre (1998), Acts of Resistance: against the tyranny of the market, The New Press: New York.

Gamble, Andrew (2009), 'Moving beyond the National: the challenges for social democracy in a global world' in Olaf Cramme and Patrick Diamond (eds) Social Justice in the Global Age, Polity Press: Cambridge.

Held, David (2004), Global Covenant: the social democratic alternative to the Washington Consensus, Polity Press: Cambridge.

Martell, Luke (2010), The Sociology of Globalization, Polity Press: Cambridge. 
Morales, Marco A., (2008), 'Have Latin Americans Turned left?', in Jorge G. Castañeda and Marco A. Morales, Leftovers: tales of the Latin American left, Routledge: London.

Mosley, Layna (2005), 'Globalization and the State: Still Room to Move?', New Political Economy, $10,3,355-62$.

Norris, Pippa (2000) 'Global Governance and Cosmopolitan Citizens' in Joseph S. Nye and John D. Donahue (eds) Governance in a Globalizing World, Washington DC: Brookings Institution Press 